UDC: $377+377.3$

DOI: https://doi.org/10.24195/2414-4665-2017-5-18

\author{
Olha Lisovska, \\ post-graduate student, Department of Pedagogy, \\ South Ukrainian National Pedagogical University named after K. D. Ushynsky, \\ 26, Staroportofrankivska, Odesa, Ukraine
}

\title{
CHARACTERISTICS OF LEVELS OF FUTURE SKILLED WORKERS' COMPETITIVNESS MATURITY
}

The components of maturity of competitiveness of future skilled workers of the service sector have been defined in the article. The criteria of maturity of stimulative and motivational, cognitive and activity, personal and reflexive components have been defined, namely: "striving for success and avoiding failures", "self-improvement", "substantial and procedural criterion", "creativity", "competitiveness", "initiative, leadership in entrepreneurship". The following levels of competitiveness maturity have been represented: the low level, the medium level, and the sufficient level. Their substantial characteristics according to the specified components have been developed. The determination of the maturity levels of competitiveness of future skilled workers of the service sector has been carried out. The generalized data of the maturity levels of competitiveness of future skilled workers of the service sector show that 21 students (20.7\%) of EG and 15 students (16.0\%) of CG have the sufficient maturity level by the criteria "striving for success and avoiding failures", "self-improvement", "substantial and procedural criterion", "creativity", "competitiveness", "initiative, leadership in entrepreneurship", which indicates that there is a small number of students who are creative, curious, have a developed imagination and the expressed risk proneness. 64 students (62.7\%) of EG and 58 students (61.7\%) of $C G$ demonstrated the medium level. Their activities are characterized by the ability for creativity, intellectual curiosity, imagination, difficulty in risk proneness. 17 students (16.6\%) of EG and 21 students (22.3\%) of CG expressed the low level. This indicates that they have an adequate self-esteem, low abilities for creativity and risk proneness. Thus, most of the students have the medium and low levels of competitiveness maturity.

Keywords: competitiveness, component, criterion, level, personality, reflection, professional educational institution, labor market.

\section{Introduction}

Social and economic transformations, which are taking place in our country, as well as the development of labor market cause changes of requirements to a future worker: his/her ability to fulfill him-/herself in his/her work and to make responsible decisions, persistence in implementation of his/her plans, adaptation skills in a market economy, etc. [1, p. 5]. Modern potential employers prefer job seekers with such abilities as creativity, competitiveness, initiative and so on. As the problems, which are associated with self-actualization of young students, are amplified by the characteristics of their personal development at the stages of acquiring professional education in professional educational institutions, an important part of the system of vocational training is the work aimed at identifying and developing the totality of certain abilities of skilled workers - educational institutions graduates, namely: inborn (based on inclinations) and acquired (based on received professional knowledge, abilities, skills).

Such scientists as L. Azov, L. Balabanova, D. Heus, P. Doil, Ya. Zhalilo, Yu. Korobov, F. Kotler, Zh. Lamben, M. Porter, L. Ramenskyi, R. Fatkhutdynov, A. Yudanov devoted their works to the issues of the theory of competition. They explored the approaches to the definition of the theory of competition, competitiveness and competitive advantages of economic entities.
The review of the scientific literature has allowed us to note that this issue was investigated in the following aspects: competitiveness as a factor of creative development of a personality (V. Andrieiev), competitiveness as a factor of future skilled workers' advantage in employment (A. Alieksieieva, L. Kapchenko, M. Myropolska, N. Savchenko), competitiveness as a means of training workers for production sphere (I. Vdovenko), etc.

However, despite its social and pedagogical importance, this issue has not been fully developed in domestic pedagogy.

The aim of the article is to characterize the maturity levels of competitiveness of future skilled workers of the service sector.

\section{Discussion}

We have identified the following components in the structure of maturity of competitiveness of future skilled workers of the service sector: stimulative and motivational, cognitive and activity, personal and reflexive. To assess the studied phenomenon, within each component we have identified the criteria and their indicators. Each criterion is aimed at evaluating an individual component with relevant indicators. Therefore, it is possible to talk about maturity of competitiveness of future skilled workers of the service sector if each criterion is found.

The stimulative and motivational component is the formation of an understanding of competitiveness and competitive struggle among the future skilled workers 
(competitive struggle is a dynamic process for more favorable working conditions among demanded employees of the enterprises, competition between employees for the best place to use their labor force [2, p. 144]; the enterprises want to attract the employees of high qualifications, high creative potential, and consequently, to assign the results of work of the main productive force - a worker to develop production, to improve the quality of goods and services, to supply the market with best goods and services, etc.), encouraging them to commit the effective activities, which are aimed at achieving the purposes; the existence of students' own stimuli for educational and cognitive activity. A full-fledged stimulus is possible in case of realizing the real significance of the knowledge, abilities and skills received at the educational institution. Therefore, it is necessary to explain the purpose of studying the material to students; deepening of motivation is a prerequisite for their positive attitude to studying. It is necessary to arouse students' internal need for the assimilation of knowledge. It can be achieved by a clear formulation of the cognitive task (usually in the form of a problem situation). As the same educational activity of students can have different motives, it is important to direct their motivation, interests and needs, to form a positive attitude towards studying.

The cognitive and activity component is the organization of practical educational and cognitive activity of students with a system of knowledge, abilities and skills, as well as the sufficient level of awareness. Its main elements are principles, methods, forms and means of training.

The effectiveness of this component is determined by the active interaction of teachers, training masters, administration of an educational institution and students, establishment of subject-subject relationships between them. In general, such a sequence of intellectual operations is provided: perception of a new material; comprehension of the information, formation of the scientific concepts; generalization; systematization; reinforcement of knowledge, abilities and skills; using them in practice.

The personal and reflexive component is the assessment by future skilled workers of their own perspectives on competitiveness on the labor market and the compliance with the requirements of the modern labor market; the students' ability to predict and adequately assess their actions and their results, as well as to assess their preparedness for professional activities; the identifying of future leadership skills, abilities for the competition, entrepreneurial abilities and creativity; orientation to success.

On the basis of the analysis, we have determined that a personality is a concrete, integral human individuality in the unity of its natural and social qualities. From the point of view of pedagogy and psychology, a personality is a certain combination of mental properties, such as orientations, features of temperament and character, abilities, peculiarities of mental processes [3, p. 243]. Reflection is a process, which is aimed at person's analyzing, understanding and awareness of him-/herself, namely his/her own actions, behavior, speech, experience, feelings, states, abilities, character, relationships with other people and attitudes towards them; his/her own tasks, mission, and so on. Procedurally and functionally, reflection is associated with introspection, retrospection, selfconsciousness and it is the main factor in regulating the behavior and personal development [4, p. 569].

Determination of the levels of competitiveness of future skilled workers is possible if there is a clear criteria base.

The analysis of the studied problem allows to note that formation of competitiveness in psychological and pedagogical literature is evaluated by various criteria, among which we can identify the criteria "striving for success and avoiding failures", "self-improvement", "substantial and procedural criterion", "creativity", "competitiveness", "initiative, leadership in entrepreneurship".

On the basis of analyzed scientific literature, we have identified and characterized the levels of maturity of competitiveness of future skilled workers of the services sector.

The low level of competitiveness maturity is characterized by low ability for creativity; low level of intellectual curiosity, imagination, difficulty in risk proneness.

At this level, future skilled workers of the service sector have theoretical knowledge of the profession and perform their work in accordance with samples, plans, support schemes, instructions and technological maps, they have the ability to apply the theoretical knowledge, which they have received, in practice, and use their knowledge in similar situations, according to the pattern.

The medium level is the basic one in the maturity of competitiveness of future skilled workers of the services sector. It is characterized by the ability for creativity, intellectual curiosity, imagination, difficulty in risk proneness. At this level, future skilled workers of the services sector have a limited amount of skills and wider competencies, which are generally common in nature; future workers are able to perform the work partially.

The sufficient level of maturity of competitiveness of future skilled workers of the service sector is characterized by intellectual curiosity, constant search for the new ways of thinking, studying various possibilities for solving the tasks, the developed imagination; expressed persistence, knowledge of complex phenomena; the expressed risk proneness, the upholding of the ideas and achievement of high goals. At this level, future skilled workers of the service sector have specific practical skills, they are able to perform the tasks independently and have limited experience of practice in a particular aspect of the work.

The aim of the experimental and research work was to diagnose the levels of maturity of competitiveness of future skilled workers of the service sector. For this purpose, 196 students were diagnosed, namely: 128 first-year and 25 third-year students of Odesa Professional Lyceum of Technologies and Design of the State institution "South Ukrainian National Pedagogical University named 
after K. D. Ushynsky" obtaining the professions "Tailor", "Hairdresser (Hairdresser-fashion designer)", "Photographer (photoworks)"; 18 first-year students of the State Educational Institution "Khmelnytskyi Center of Professional and Technical Education in the Service Sector"; 25 first-year students of a separate structural department "United Higher Professional and Technical College of the
Service Sector of the National University "Odessa Law Academy".

The experimental group included 102 students, the control group included 194 students.

The generalized data on the levels of maturity of competitiveness of future skilled workers of the service sector are presented in Table 1 and Diagram 1.

Table 1.

General levels of maturity of competitiveness of future skilled workers of the service sector

\begin{tabular}{|c|c|c|c|c|}
\hline \multirow{2}{*}{$\begin{array}{c}\text { Levels of } \\
\text { competitiveness ma- } \\
\text { turity }\end{array}$} & \multicolumn{2}{|c|}{ EG/ } & \multicolumn{2}{c|}{ CG/ } \\
\cline { 2 - 5 } & $\begin{array}{c}\text { Number of stu- } \\
\text { dents }\end{array}$ & $\%$ & $\begin{array}{c}\text { Number of stu- } \\
\text { dents }\end{array}$ & $\%$ \\
\hline Low & 17 & 16.6 & 21 & 22.3 \\
\hline Medium & 64 & 62.7 & 58 & 61.7 \\
\hline Sufficient & 21 & 20.7 & 15 & 16.0 \\
\hline
\end{tabular}

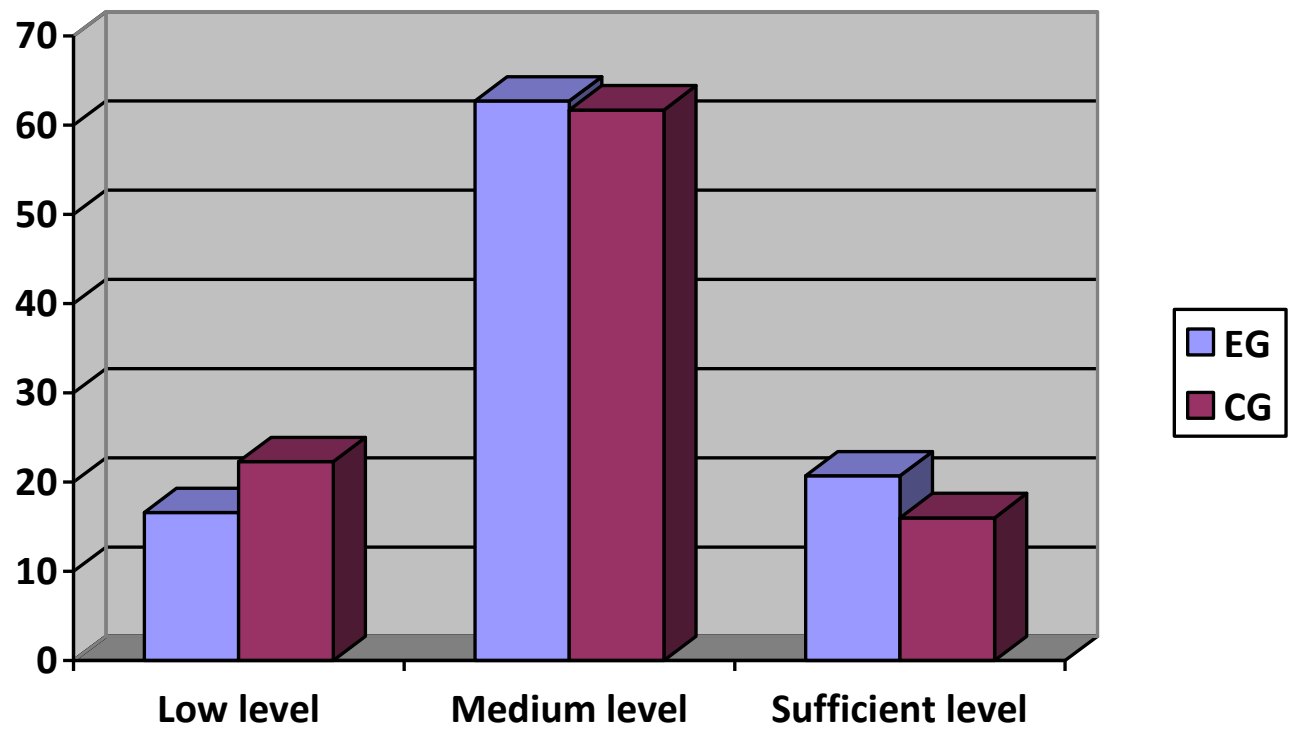

Fig. 1. General levels of maturity of competitiveness of future skilled workers of the service sector

Thus, the data presented in Table 1 and Diagram 1 show that 21 students $(20.7 \%)$ of EG and 15 students $(16.0 \%)$ of CG have the sufficient maturity level by the criteria "striving for success and avoiding failures", "selfimprovement", "substantial and procedural criterion", "creativity", "competitiveness", "initiative, leadership in entrepreneurship", which indicates that there is a small number of students who are creative, curious, have a developed imagination and the expressed risk proneness. 64 students $(62.7 \%)$ of EG and 58 students $(61.7 \%)$ of CG demonstrate the medium level. Their activities are characterized by the ability for creativity, intellectual curiosity, imagination, difficulty in risk proneness. 17 students

\section{REFERENCES}

1. Poiasniuvalna zapyska do proektu Zakonu Ukrainy "Pro profesiinu osvitu» [Explanatory note to the draft Law of Ukraine "On Professional Education"].
(16.6\%) of EG and 21 students $(22.3 \%)$ of CG express the low level. This indicates that they have an adequate selfesteem, low abilities for creativity and risk proneness.

Conclusions. Based on the results of the diagnostics of the maturity levels of competitiveness of future skilled workers of the service sector, there has been defined that most of the students have the medium and low levels of competitiveness maturity.

The perspective direction of our further researches is creating corresponding pedagogical conditions in professional educational institutions of the services sector, which will make it possible to the increase the maturity level of competitiveness of future skilled workers.

Retrieved

from: http://search.ligazakon.ua/1_doc2.nsf/link1/GH3ZC1AA.h tml [in Ukrainian]. 
2. Petrova, I. (1997). Sehmentatsiia rynku pratsi: teoriia $i$ praktyka rehuliuvannia [Segmentation of the labor market: theory and practice of regulation]. Kyiv: In-t ekonomiky, upravlinnia ta hospodarskoho prava [in Ukrainian].

\section{ЛІТЕРАТУРА}

1. Пояснювальна записка до проекту Закону України «Про професійну освіту» [Електронний ресурс]. http://search.ligazakon.ua/1_doc2.nsf/link1/GH3ZC1AA.h tml.

2. Петрова І. Л. Сегментація ринку праці: теорія і практика регулювання / I. Л. Петрова. - К. : Ін-т економіки, управління та господарського права, 1997.
3. Honcharenko, S. (1997). Ukrainskyi pedahohichnyi slovnyk [Ukrainian Pedagogical Dictionary]. Kyiv: Lybid [in Ukrainian].

4. Meshcheryakova, B. G., Zinchenko, V. P. (2009). Bolshoy psikhologicheskiy slovar [Great psychological dictionary]. Moscow: AST MOSKVA; St. Petersburg: Praym-EVROZNAK [in Russian].

$-298 \mathrm{c}$.

3. Гончаренко С. Український педагогічний словник / Семен Гончаренко. - Київ : Либідь, 1997. $376 \mathrm{c}$.

4. Большой психологический словарь / Сост. и общ. Ред. Б. Г. Мещерякова, В. П. Зинченко. - М. : АСТ: АСТ МОСКВА; СПб. : Прайм-ЕВРОЗНАК, 2009. $-811 \mathrm{c}$

\section{Південноукраїнський національний педагогічний університет імені К. Д. Уиинського, вул. Старопортофранківська, 26, м. Одеса, Україна} Ольга Михайлівна Лісовська,
аспірант кафедри педагогіки,

\section{ХАРАКТЕРИСТИКА РІВНІВ СФОРМОВАНОСТІ КОНКУРЕНТОСПРОМОЖНОСТІ МАЙБУТНІХ КВАЛІФІКОВАНИХ РОБІТНИКІВ}

У статті визначено компоненти сформованості конкурентоспроможності майбутніх кваліфікованих робітників професійних навчальних закладів сфери послуг. Визначено критерії сформованості стимулювальномотиваційного, конгітивно-діяльнісного та особистісно-рефлексивного компонентів: «прагнення до успіху та уникнення невдач», «самовдосконаленість», «змістовно-процесуальний», «креативність», «конкурентоздатність», «ініціативність, лідерство у підприємництві». Встановлено рівні сформованості конкурентоспроможності: низький, середній, достатній. Розроблено їхні змістовні характеристики за означеними компонентами. Проведено діагностику щодо визначення рівнів сформованості конкурентоспроможності майбутніх кваліфікованих робітників професійних навчальних закладів сфери послуг. Із цією метою було проведено діагностування серед 196 учнів. До експериментальної групи увійшли учні у кількості 102 особи, до контрольної - 94. За критеріями «прагнення до успіху та уникнення невдач», «самовдосконаленість», «змістовно-процесуальний», «креативність», «конкурентоздатність», «ініціативність, лідерство у підприємництві» на достатньому рівні було зафіксовано 21 учні (20,7\%) ЕГ і 15 учнів (16,0\%) КГ, що свідчить про незначну кількість учнів, які є креативними, допитливими, мають розвинену уяву, виражену схильність до ризику. Середній рівень продемонстрували 64 учні (62,7\%) ЕГ і 58 учнів (61,7\%) КГ, у яких відбувається формування креативності. Їхня діяльність характеризується наявністю здатності до творчості, допитливості, уяви, складності та схильності до ризику. Низький рівень виявили 17 учнів (16,6\%) ЕГ і 21 учень (22,3\%) КГ. Це свідчить про те, що вони мають адекватну самооцінку, низький рівень здатності до творчості та схильності до ризику. Виходячи з результатів діагностики щодо визначення рівнів сформованості конкурентоспроможності майбутніх кваліфікованих робітників професійних навчальних закладів сфери послуг, було визначено, що більшість учнів мають середній та низький рівні сформованості конкурентоспроможності. Перспективним напрямком наших подальших досліджень $є$ забезпечення відповідних педагогічних умов у професійному навчальному закладі сфери послуг, від яких залежить підвищення рівня конкурентоспроможності майбутніх кваліфікованих робітників.

Ключові слова: конкурентоспроможність, компонент, критерій, рівень, особистість, рефлексія, професійний навчальний заклад, ринок робочої сили.

Reviewed by Doctor of Pedagogy, prof. I. Buzhyna 